\title{
Significance of thresholds in integrated methods of weeding regulation in cereals
}

\section{Znaczenie progów szkodliwości w integrowanych metodach regulacji zachwaszczenia w zbożach}

\author{
Henryka Rola ${ }^{1}$, Krzysztof Domaradzki $^{1}$, Sylwia Kaczmarek ${ }^{2}$, Jan Kapeluszny ${ }^{3}$
}

\begin{abstract}
Summary
Based on the long-term research on weed competitions of in cereals, the biological and economic thresholds for weeds were shown, depending on: weed species and their competitiveness, fertilization, seeding rate of crop, level of crop yielding and competition capacity of cultivars crop. The competitiveness of weeds to cereals was differentiated and depended on their species composition. Among the investigated weeds species the most competitive was Cirsium arvense, followed by Centaurea cyanus, Galium aparine, Anthemis arvensis, Avena fatua and Apera spica-venti. The results from these investigations may support the decisions support in the integrated system for weeding regulation in cereals.
\end{abstract}

Key words: herbicide, threshold for weeds, integration weeding system, cereals

\section{Streszczenie}

Bazując na długoletnich badaniach konkurencyjności chwastów w zbożach, zaprezentowano wyniki doświadczeń określających biologiczne i ekonomiczne progi szkodliwości chwastów w zależności od: ich konkurencyjności, nawożenia, normy wysiewu rośliny uprawnej i jej poziomu plonowania. Konkurencyjność chwastów w stosunku do zbóż jest zróżnicowana i zależy od gatunku. Najbardziej konkurencyjnym gatunkiem spośród badanych był Cirsium arvense, a w następnej kolejności Centaurea cyanus, Galium aparine, Anthemis arvensis, Avena fatua i Apera spica-venti. Wyniki doświadczeń mogą być pomocne w podejmowaniu decyzji w integrowanych systemach regulacji zachwaszczenia w zbożach.

Słowa kluczowe: herbicydy, progi szkodliwości chwastów, regulacja zachwaszczenia zbóż

\footnotetext{
Instytut Uprawy Nawożenia i Gleboznawstwa - Państwowy Instytut Badawczy

Orzechowa 61, 50-540 Wrocław

k.domaradzki@iung.wroclaw.pl

${ }^{2}$ Instytut Ochrony Roślin - Państwowy Instytut Badawczy

Władysława Węgorka 20, 60-318 Poznań

${ }^{3}$ Uniwersytet Przyrodniczy w Lublinie

Katedra Herbologii i Technik Uprawy Roślin

Akademicka 13, 20-950 Lublin
} 


\section{Wstęp / Introduction}

Właściwa strategia zapobiegania nadmiernemu zachwaszczeniu agrocenoz powinna uwzględniać programy decyzyjne, zalecane na podstawie znajomości progów szkodliwości poszczególnych gatunków chwastów lub całych zbiorowisk występujących w roślinach uprawnych. Wykorzystanie ich w agrotechnice uprawy roślin stanowi ważny element integrowanych metod ochrony roślin przed agrofagami. Przyczynia się do ograniczenia kosztów regulacji zachwaszczenia oraz zmniejszenia ryzyka zanieczyszczenia środowiska przez ograniczenie stosowania herbicydów do koniecznego minimum.

W wielu pracach naukowych udowodniono, że chwasty są silnymi konkurentami roślin uprawnych o wodę, światło i składniki pokarmowe (Zimdahl 1980). Znany jest pogląd, że na polach silnie zachwaszczonych, straty makroskładników dostarczonych w postaci nawozów mineralnych i organicznych dochodzą do 70\%. Jak podaje Libersztajn (1981), chwasty występujące w łanie w liczbie 100 osobników $/ \mathrm{m}^{2}$ pobierają $\mathrm{z}$ gleby $60-140 \mathrm{~kg}$ azotu, $20-30 \mathrm{~kg}$ fosforu i 100-140 kg potasu $\mathrm{z}$ powierzchni 1 ha, co wystarczyłoby do uzyskania plonu ziarna pszenicy ozimej w wysokości 3 ton $\mathrm{z} 1$ ha. W konkurencji o wodę zwyciężają zwykle chwasty, ponieważ mają w porównaniu ze zbożami lepiej rozbudowany system korzeniowy, większą siłę ssącą korzeni oraz szybsze tempo ich wzrostu (Donald 1951; Duer 1975). Finalnym skutkiem konkurencji są straty w plonach roślin uprawnych. Wielkość tych strat zależy od wielu czynników, z których za najważniejszy uważa się stan i stopień zachwaszczenia łanu. Istota wyeliminowania chwastów $\mathrm{z}$ łanów roślin uprawnych polega na racjonalnym ograniczaniu ich konkurencji przez regulację występowania dowolną, ale skuteczną metoda, $\mathrm{w}$ tym również odpowiednio dobranymi herbicydami. Zabieg uważa się za skuteczny, jeżeli osłabia kondycję chwastów, zaburza ich kwitnienie i owocowanie, a przede wszystkim zmniejsza liczebność populacji gatunków szkodliwych, do poziomu niezagrażającego stabilnemu plonowaniu. Nowoczesne podejście do problemu zwalczania chwastów w rolnictwie integrowanym polega na racjonalnym, tzn. uwzględniającym rachunek ekonomiczny, łączeniu efektywnych i bezpiecznych dla środowiska metod, w celu zmniejszenia liczebności zbędnej roślinności segetalnej do poziomu nazywanego ekonomicznym progiem szkodliwości chwastów występujących w łanie.

Zainteresowanie $w$ nauce światowej zagadnieniem progów szkodliwości chwastów w roślinach uprawnych, przypada na drugą połowę 20. wieku. Również w Polsce, poznanie zależności pomiędzy nasileniem występowania określonych gatunków chwastów w łanie a ich ujemnym wpływem na plonowanie roślin uprawnych, znalazło się w centrum zainteresowań i badań w kilku ośrodkach naukowo-badawczych.

Celem opracowania jest przeglądowe przedstawienie dotychczasowych wyników badań przeprowadzonych w Polsce nad ustaleniem progów szkodliwości chwastów, $\mathrm{z}$ uwzględnieniem ich znaczenia $\mathrm{w}$ strategii $\mathrm{w}$ integrowanej ochronie upraw zbożowych, zgodnej z zasadami dobrej praktyki rolniczej oraz ochrony środowiska.

\section{Materiały i metody / Materials and methods}

Już w latach 80. XX wieku w Instytucie Uprawy Nawożenia i Gleboznawstwa we Wrocławiu oraz Akademii Rolniczej w Lublinie realizowano intensywne badania nad wpływem dominujących gatunków chwastów na plonowanie zbóż, rzepaku, buraka cukrowego i kukurydzy (Kapeluszny i Pawłowski 1978; Rola 1982; Kapeluszny 1988a, b). Powyższe badania w ostatnich latach są kontynuowane w Instytucie Uprawy Nawożenia i Gleboznawstwa - Państwowym Instytucie Badawczym (Domaradzki i wsp. 2010), a także są uwzględniane w programach badawczych Instytutu Ochrony Roślin - Państwowego Instytutu Badawczego w Poznaniu (Kaczmarek i Adamczewski 2007). Uzyskane wyniki stały się przydatne dla szerokiej praktyki rolniczej, poprzez możliwość prognozowania ekonomicznej efektywności zabiegów chemicznej regulacji zachwaszczenia roślin uprawnych.

W latach 1972-2008, zgromadzono wyniki analiz struktury plonu zbóż, uprawianych w warunkach doświadczeń mikropoletkowych i na polach produkcyjnych. W badaniach na mikropoletkach, o powierzchni $1-2 \mathrm{~m}^{2}$ obsianych pszenicą ozimą, żytem ozimym lub jęczmieniem jarym, uprawianych w kontrolowanych warunkach agrotechnicznych, o stałej liczbie roślin na jednostce powierzchni, ustalono wpływ różnej liczby chwastów na $1 \mathrm{~m}^{2}$ na plonowanie zbóż. Nasiona chwastów podsiewano łącznie z siewem zbóż, a po wschodach przerywano je do ustalonej liczby: $0,5,10,25,50,100$ siewek na $1 \mathrm{~m}^{2}$. Obsadę taką utrzymywano aż do zbioru, a stan ten kilkakrotnie kontrolowano w czasie wegetacji. Podczas zbiorów oznaczano plon ziarna $\mathrm{z}$ powierzchni $1 \mathrm{~m}^{2}$ oraz niektóre elementy jego struktury, jak: liczbę kłosów, liczbę ziaren w kłosie, średnią długość kłosa oraz masę 1000 ziaren. W ten sposób badano oddziaływanie takich gatunków chwastów, jak: Alopecurus myosuroides, Apera spicaventi, Bromus sterillis, Centaurea cyanus, Galium aparine, Matricaria maritima ssp. indora i Veronica persica.

Badania na polach produkcyjnych, polegały na wyborze łanów zbóż o zróżnicowanym stopniu zachwaszczenia jednym $z$ badanych gatunków chwastów, $z$ ewentualnym niewielkim udziałem (do 5\%) innych gatunków towarzyszących. Wybierane do badań uprawy z odpowiednim zachwaszczeniem charakteryzowały się dobrym wyrównaniem łanu rośliny zbożowej, tzn. bez wypadów i przerzedzeń spowodowanych np. zmiennością glebową, niedoborem składników pokarmowych, niekorzystnym przebiegiem pogody lub porażeniem przez szkodniki i choroby. Wyboru takich pól dokonywano krótko przed zbiorem zbóż. Próby kłosów pobierano z powierzchni $1 \mathrm{~m}^{2}$, wyznaczonych za pomocą ramki o powierzchni $1 \mathrm{~m}^{2}$, w miejscach różniących się nasileniem występowania przedmiotowego gatunku chwastu, po uprzednim ich przeliczeniu. Stopnie zachwaszczenia $(0,5,10,25,50$ roś$\mathrm{lin} / \mathrm{m}^{2}$ ) traktowano jako obiekty eksperymentu, natomiast wielokrotność prób o podobnym nasileniu występowania chwastów, jako powtórzenia. Pobrane próby kłosów podlegały analizie struktury plonu. Ogółem w latach 1978-2008, przeanalizowano ponad 4000 prób kłosów pochodzących z upraw zbóż, na których w zbiorowiskach segetalnych dominowały: A. spica-venti, Avena fatua, 
Elymus repens, A. myosuroides, C. cyanus, Chenopodium album, Cirsium arvense, G. aparine, M. maritima ssp. indora, Sinapis arvensis, $V$. persica.

Uzyskane wyniki poddano analizie statystycznej, a na podstawie strat $\mathrm{w}$ plonach ziarna $\mathrm{w}$ zależności od liczebności na $1 \mathrm{~m}^{2}$ występującego $\mathrm{w}$ łanie badanego gatunku chwastu wyznaczono:

- biologiczny próg szkodliwości, określający minimalne zachwaszczenie, które powoduje wymierną obniżkę plonu lub pogorszenie jego jakości,

- ekonomiczny próg szkodliwości, charakteryzujący stopień zachwaszczenia, przy którym wartość obniżonego plonu równa jest kosztom zastosowanej metody zwalczania,

- ekonomiczną efektywność odchwaszczania, określającą wartość uratowanego od straty plonu w wyniku zastosowanego zabiegu, pomniejszoną o koszty poniesione na wykonanie tego zabiegu.

Bilans ekonomiczny (B) strat w plonach roślin uprawnych spowodowanych przez określony stopień zachwaszczenia łanu w relacji do kosztów poniesionych w wyniku zastosowania herbicydu obliczano według wzoru:

$$
B=p \times s \times c-(h+z+s m): 100
$$

$\mathrm{p}=$ oczekiwany plon $\mathrm{w}$ przypadku gdyby uprawa była wolna od chwastów [t/ha]; $\mathrm{s}=\%$ strata plonu ustalona doświadczalnie; $\mathrm{c}=$ cena 1 tony produktu; $\mathrm{h}=$ koszt herbicydu [PLN/ha]; $\mathrm{z}=$ koszt usługi [PLN/ha]; sm = straty plonu w \% spowodowane przez inne czynniki (np. uszkodzenia mechaniczne).

Objaśnienie wyniku:

Bilans ekonomiczny (B) o wartości ujemnej wskazuje, że zastosowanie herbicydu przy stwierdzonym stopniu zachwaszczenia pola jest niecelowe, natomiast B o wartości zbliżonej do 0 oznacza ekonomiczny próg szkodliwości występującego w łanie gatunku chwastu. B o wartości dodatniej oznacza ekonomiczną celowość wykonania zabiegu odchwaszczającego, tzn. że aplikacja herbicydu daje zysk w postaci zwyżki plonu, a zatem zabieg odchwaszczania jest ekonomicznie celowy.

Ustalone eksperymentalnie progi szkodliwości wynikające ze strat w plonach pszenicy ozimej, spowodowane istniejącym stanem zachwaszczenia $A$. spica-venti, stanowiły podstawę do określenia ich zmienności w zależności od takich czynników, jak: gatunek chwastu i jego siła konkurencyjna, rodzaj gleby i poziom agrotechniki, nawożenie, ilość wysiewu rośliny uprawnej, poziom plonowania rośliny uprawnej, układ przestrzenny roślin w łanie, zdolność konkurencyjna rośliny uprawnej.

\section{Wyniki i dyskusja / Results and discussion}

\section{Gatunek chwastu i jego konkurencyjność Weed species and its competitiveness}

$\mathrm{Na}$ podstawie badań przeprowadzonych w latach 1969-2006 przez Zakład Ekologii i Zwalczania Chwastów,
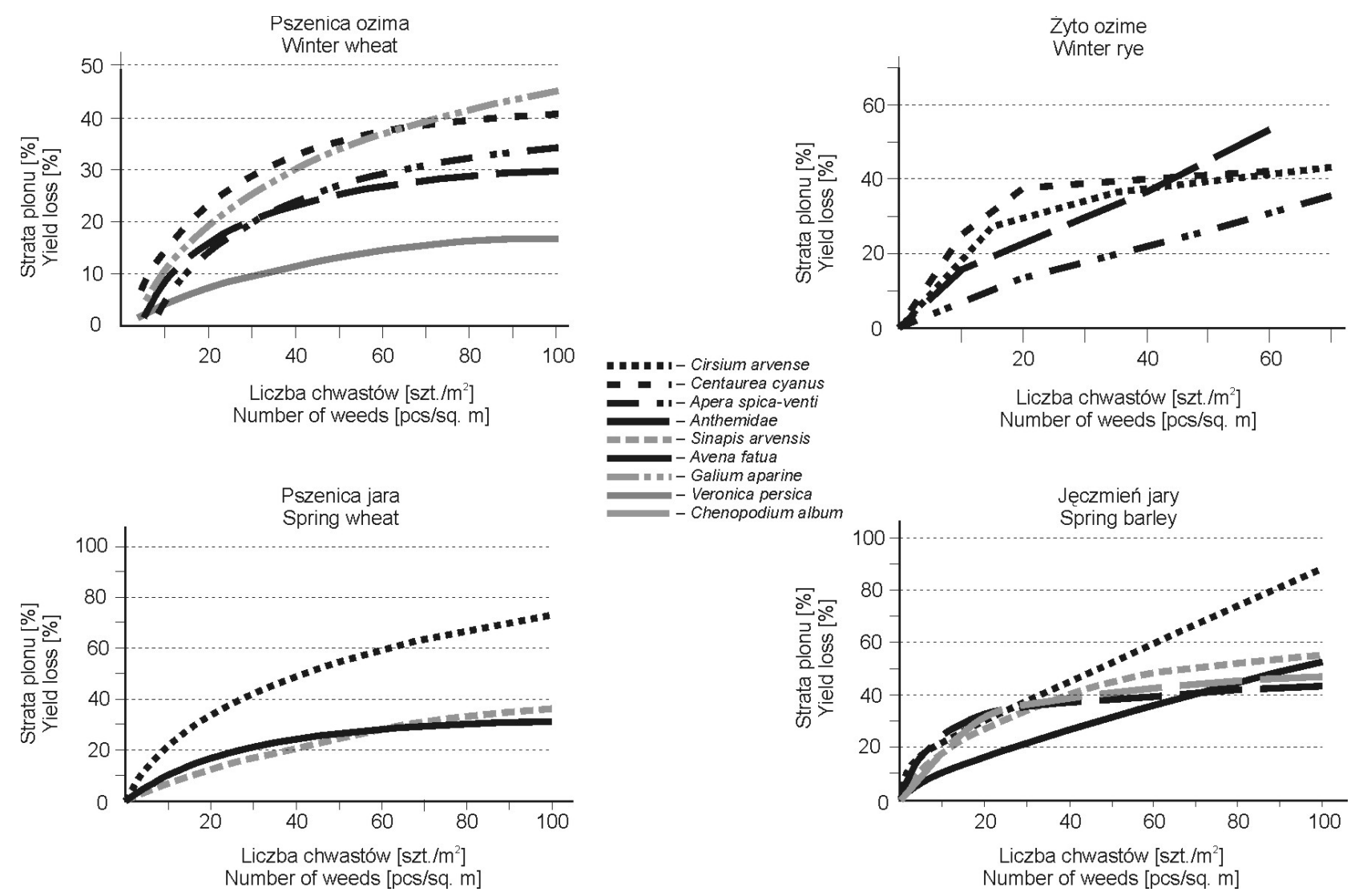

Rys. 1. Wpływ stopnia zachwaszczenia przez różne gatunki na obniżenie plonu zbóż w \% (Rola i Rola 2002)

Fig. 1. Influence of weed infestation by different species on the cereals yield increase in \% (Rola i Rola 2002) 
Tabela 1. Ekonomiczne progi szkodliwości chwastów występujących w pszenicy ozimej (na podstawie badań autorów)

Table 1. The economic thresholds for weed harmfulness in winter wheat (on the base author's research)

\begin{tabular}{|c|c|c|c|}
\hline $\begin{array}{c}\text { Gatunki chwastów } \\
\text { Weeds species }\end{array}$ & $\begin{array}{c}\text { Liczba roślin } / \mathrm{m}^{2} \\
\text { Number of plants } / \mathrm{m}^{2}\end{array}$ & $\begin{array}{l}\text { Roślina uprawna } \\
\text { Crop }\end{array}$ & $\begin{array}{l}\text { Autor } \\
\text { Author }\end{array}$ \\
\hline Alopecurus myosuroides & 5 & $\begin{array}{l}\text { pszenica ozima } \\
\text { winter wheat }\end{array}$ & $\begin{array}{l}\text { Domaradzki i Rola } 2006 \\
\text { Domaradzki i wsp. } 2010\end{array}$ \\
\hline Anthemis arvensis & $2-5$ & $\begin{array}{l}\text { pszenica ozima, żyto } \\
\text { winter wheat, rye }\end{array}$ & Rola 1982 \\
\hline Apera spica-venti & $5-10$ & $\begin{array}{l}\text { pszenica ozima, żyto, } \\
\text { winter wheat, rye } \\
\text { pszenica ozima } \\
\text { winter wheat } \\
\text { pszenica ozima, żyto } \\
\text { winter wheat, rye }\end{array}$ & $\begin{array}{l}\text { Rola 1982, 1983, 1985, } 1986 \\
\text { Kapeluszny } 1986 \\
\text { Kaczmarek i Adamczewski } 2007\end{array}$ \\
\hline Avena fatua & $26-50$ & $\begin{array}{l}\text { pszenica ozima, pszenica jara } \\
\text { winter wheat, spring wheat }\end{array}$ & $\begin{array}{l}\text { Rola } 1985 \\
\text { Kapeluszny 1986a, b }\end{array}$ \\
\hline Bromus sterilis & 5 & $\begin{array}{l}\text { pszenica ozima, żyto } \\
\text { winter wheat, rye }\end{array}$ & Kaczmarek i Adamczewski 2007 \\
\hline Centaurea cyanus & $1-5$ & $\begin{array}{l}\text { pszenica ozima } \\
\text { winter wheat }\end{array}$ & $\begin{array}{l}\text { Kapeluszny i Pawłowski } 1978 \\
\text { Rola } 1982\end{array}$ \\
\hline Cirsium arvense & $1-2$ & $\begin{array}{l}\text { pszenica jara } \\
\text { summer wheat }\end{array}$ & Rola 1992 \\
\hline Elymus repens & $10-15$ & $\begin{array}{l}\text { pszenica ozima } \\
\text { winter wheat }\end{array}$ & Kapeluszny 1988 \\
\hline Galium aparine & $2-5$ & $\begin{array}{l}\text { pszenica ozima } \\
\text { winter wheat }\end{array}$ & Rola 1982 \\
\hline Matricaria maritima ssp. inodora & 10 & $\begin{array}{l}\text { pszenica ozima } \\
\text { winter wheat }\end{array}$ & $\begin{array}{l}\text { Kapeluszny i Pawłowski } 1978 \\
\text { Rola } 1982\end{array}$ \\
\hline Papaver rhoeas & $6-10$ & $\begin{array}{l}\text { pszenica ozima } \\
\text { winter wheat }\end{array}$ & Kapeluszny 1988 \\
\hline Veronica persica & $10-25$ & $\begin{array}{l}\text { pszenica ozima } \\
\text { winter wheat }\end{array}$ & Rola 1982 \\
\hline
\end{tabular}

a od 2006 roku do chwili obecnej przez Zakład Herbologii i Technik Uprawy Roli Instytutu Uprawy Nawożenia i Gleboznawstwa - Państwowego Instytutu Badawczego we Wrocławiu, Katedrę Herbologii i Technik Uprawy Roślin Uniwersytetu Przyrodniczego w Lublinie oraz Zakład Herbologii i Techniki Ochrony Roślin Instytutu Ochrony Roślin - Państwowego Instytutu Badawczego w Poznaniu stwierdzono, że wraz ze wzrastającą liczebnością chwastów w łanie zbóż i w zależności od gatunku, jaki dominuje, maleją plony, co jednocześnie oznacza rosnące straty (rys. 1).

Wymierne starty plonu ziarna zbóż, na skutek zachwaszczenia, powstają w efekcie pogorszenia się niektórych elementów struktury łanu i plonu, a więc obniżenia obsady roślin i kłosów na jednostce powierzchni liczby ziaren w kłosie oraz ich masy (Kapeluszny i Pawłowski 1978; Rola 1982; Kaczmarek i Adamczewski 2007). Konkurencyjność chwastów w stosunku do zbóż jest różna i w przypadku ich masowego występowania w łanie, wielkość spadku plonu zależeć będzie od siły konkurencyjnej gatunku dominującego. $\mathrm{Z}$ przedstawionych na rysunku 1 . strat w plonach zbóż, wynika, że najbardziej konkurencyjnym gatunkiem spośród badanych był $C$. arvense, którego obecność w łanie może spowodować obniżenie plonów ziarna nawet o ponad $60 \%$. W dalszej kolejności pod kątem szkodliwości należy wymienić: C. cyanus,
G. aparine, Anthemis arvensis, A. fatua i A. spica-venti. Dane te stanowiły podstawę do ustalenia progów szkodliwości określonych gatunków chwastów występujących w uprawach.

Progi ekonomicznej szkodliwości wymienionych gatunków chwastów wyrażone liczbą roślin na $1 \mathrm{~m}^{2}$ przedstawiono w tabeli 1.

Przyjęte wskaźniki progowe mogą mieć zastosowanie praktyczne, jeżeli jeden z wymienionych gatunków chwastów jest w przewadze, a gatunki towarzyszące występują sporadycznie. Nie są to jednak przypadki rzadkie. Nawet bardzo powierzchowne obserwacje pól zbożowych dowodzą, że w większości łanów lista florystyczna jest dość uboga, jeśli dominująco występują w nich: $G$. aparine, A. arvensis, M. maritima ssp. inodora czy A. spicaventi. Należy przy tym zaznaczyć, że zachwaszczenie jednogatunkowe jest dla większości upraw bardziej groźne niż wielogatunkowe, bo siedlisko wykorzystywane jest jednostronnie. Przykładem mogą być chwasty azotolubne, jak G. aparine i M. maritima ssp. inodora, które pobierają azot wniesiony do gleby $\mathrm{z}$ nawozami, pozbawiając tego składnika roślinę uprawną. Uproszczoną lecz dla praktyki bardzo przydatną, informację o wielkościach ekonomicznych progów szkodliwości oraz efektywności zabiegu herbicydowego można uzyskać, przedstawiając straty $\mathrm{w}$ plonach spowodowane przez dominujące gatunki chwas- 
Tabela 2. Wpływ chwastów na plonowanie pszenicy ozimej

Table 2. The influence of weeds on winter wheat yielding

\begin{tabular}{|c|c|c|c|c|c|c|}
\hline \multirow{2}{*}{$\begin{array}{c}\text { Gatunek chwastu } \\
\text { Weed species }\end{array}$} & \multirow{2}{*}{$\begin{array}{l}\text { Liczba roślin } \\
\text { na } 1 \mathrm{~m}^{2} \\
\text { Number of plants } \\
\text { per sq. meter }\end{array}$} & \multicolumn{3}{|c|}{$\begin{array}{l}\text { Straty plonu ziarna pszenicy ozimej } \\
\text { Loss of grain yield of winter wheat }\end{array}$} & \multirow{2}{*}{$\begin{array}{c}\text { Koszt } \\
\text { odchwaszczania } \\
\text { Cost of weed } \\
\text { control } \\
{[\text { PLN/ha] }}\end{array}$} & \multirow{2}{*}{$\begin{array}{c}\text { Efektywność } \\
\text { zabiegu } \\
\text { Effectivenes } \\
\text { of application }\end{array}$} \\
\hline & & {$[\%]$} & {$[\mathrm{kg} / \mathrm{ha}]$} & [PLN/ha] & & \\
\hline $\begin{array}{l}\text { Apera spica- } \\
\text { venti }\end{array}$ & $\begin{array}{r}5 \\
10 \\
25 \\
50\end{array}$ & $\begin{array}{r}1 \\
6 \\
16 \\
27\end{array}$ & $\begin{array}{r}45 \\
270 \\
720 \\
1215\end{array}$ & $\begin{array}{r}38 \\
229 \\
612 \\
1032\end{array}$ & $205(1)^{*}$ & $\begin{array}{l}- \\
+ \\
+ \\
+\end{array}$ \\
\hline Avena fatua & $\begin{array}{r}5 \\
10 \\
25 \\
50\end{array}$ & $\begin{array}{r}1 \\
2 \\
8 \\
11 \\
\end{array}$ & $\begin{array}{r}45 \\
90 \\
360 \\
495 \\
\end{array}$ & $\begin{array}{r}38 \\
76 \\
306 \\
420 \\
\end{array}$ & $260(3)^{*}$ & $\begin{array}{l}- \\
- \\
+ \\
+\end{array}$ \\
\hline Anthemis arvensis & $\begin{array}{r}2 \\
10 \\
25 \\
50\end{array}$ & $\begin{array}{r}3 \\
8 \\
16 \\
24\end{array}$ & $\begin{array}{r}135 \\
360 \\
720 \\
1080\end{array}$ & $\begin{array}{l}114 \\
306 \\
612 \\
918\end{array}$ & $140(2)^{*}$ & $\begin{array}{l}- \\
+ \\
+ \\
+\end{array}$ \\
\hline Centaurea cyanus & $\begin{array}{r}5 \\
10 \\
25 \\
50 \\
\end{array}$ & $\begin{array}{r}6 \\
15 \\
24 \\
30\end{array}$ & $\begin{array}{r}270 \\
675 \\
1080 \\
1350 \\
\end{array}$ & $\begin{array}{r}229 \\
573 \\
918 \\
1147 \\
\end{array}$ & $140(2)^{*}$ & $\begin{array}{l}+ \\
+ \\
+ \\
+\end{array}$ \\
\hline Cirsium arvense & $\begin{array}{r}1 \\
5 \\
10 \\
15 \\
\end{array}$ & $\begin{array}{r}5 \\
19 \\
28 \\
36\end{array}$ & $\begin{array}{r}315 \\
855 \\
1260 \\
1620 \\
\end{array}$ & $\begin{array}{r}267 \\
726 \\
1071 \\
1377 \\
\end{array}$ & $190(4)^{*}$ & $\begin{array}{l}- \\
+ \\
+ \\
+ \\
+\end{array}$ \\
\hline Galium aparine & $\begin{array}{r}2 \\
10 \\
25 \\
50\end{array}$ & $\begin{array}{r}4 \\
12 \\
22 \\
32\end{array}$ & $\begin{array}{r}180 \\
540 \\
990 \\
1440\end{array}$ & $\begin{array}{r}153 \\
459 \\
841 \\
1224\end{array}$ & $200(5)^{*}$ & $\begin{array}{l}+ \\
+ \\
+ \\
+\end{array}$ \\
\hline
\end{tabular}

Średni plon pszenicy ozimej - 4,5 t/ha, cena 1 tony ziarna pszenicy - 850 PLN (dane z lutego 2012 r.)

Average yield of winter wheat $-4.5 \mathrm{t} / \mathrm{ha}$, price $1 \mathrm{t}$ wheat grains -850 PLN (data from February 2012)

Cena herbicydu - Price of herbicide:

$(1)^{*}-$ Arelon Fox 2,5 1/ha - 125 PLN/ha; $(2)^{*}$ - Chwastox Trio 540 SL 2,0 1/ha - 60 PLN/ha; (3) ${ }^{*}$ - Puma Universal 069 EW 1,2 1/ha - 180 PLN/ha; $(4)^{*}$ - Lontrel $300 \mathrm{SL} 0,3$ 1/ha $-110 \mathrm{PLN} / \mathrm{ha} ;(5)^{*}$ - Starane 250 EC 0,8 1/ha $-120 \mathrm{PLN} / \mathrm{ha}$

Koszt wykonania zabiegu - Cost of application - 80 PLN/ha

Koszt odchwaszczania 1 ha w kg ziarna pszenicy (koszt herbicydów + koszt wykonania zabiegu) - Cost of weed control of 1 ha in kg wheat grain (price of herbicides + cost of application)

Efektywność zabiegu herbicydowego: - nieuzasadniony; + ekonomicznie uzasadniony

Effectiveness of herbicide applications: - unjustified + economicaly justified

tów występujące w danej uprawie oraz koszty ich chemicznego zwalczania wyrażając je ekwiwalentem uzyskanego produktu i jego ceną (tab. 2).

Jak wskazują dotychczasowe wyniki badań, konkurencyjne oddziaływanie chwastów na wzrost i rozwój zbóż jest zjawiskiem złożonym, a progi szkodliwości są różne dla poszczególnych gatunków chwastów i zmienne, zależne od wielu czynników agroekologicznych.

\section{Gleba / Soil}

Ten sam gatunek chwastu może konkurować z rośliną uprawną w różnym stopniu w zależności od rodzaju gleby, na jakiej występuje lub od gatunku i odmiany zboża, w którym rośnie. Na przykład $A$. spica-venti na glebach lżejszych jest mniej konkurencyjna w stosunku do pszenicy niż na glebach cięższych. Jest to uwarunkowane słabszym rozwojem $A$. spica-venti na glebach lżejszych, która posiadając dobrze rozwinięty, ale dość płytki system korzeniowy ma mniejsze możliwości korzystania ze składników pokarmowych i wody (rys. 2). Dlatego próg szkodliwości tego gatunku w pszenicy na glebach lżejszych będzie wyższy (Rola 1982).

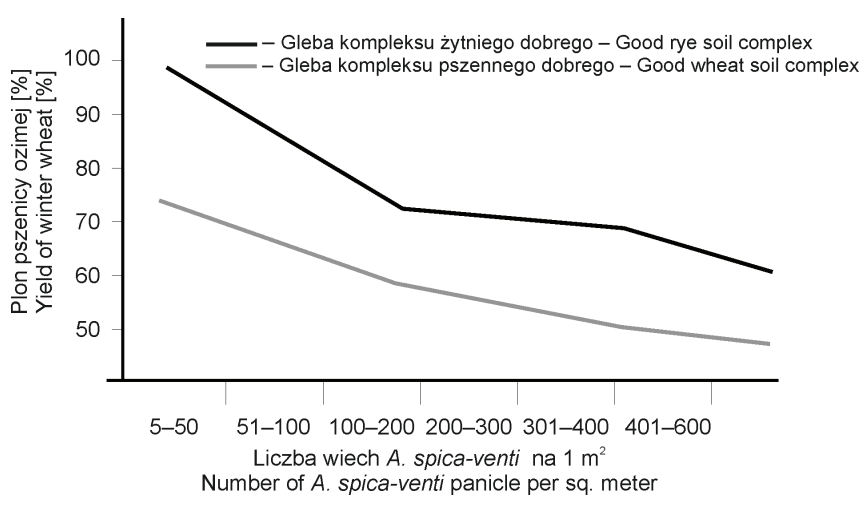

Rys. 2. Wpływ gatunku A. spica-venti na plonowanie pszenicy ozimej uprawianej na różnych glebach (Rola i Rola 2002)

Fig. 2. Influence of $A$. spica-venti species on the winter wheat yield cultivated on different type of soil (Rola i Rola 2002) 


\section{Gęstość wysiewu rośliny uprawnej i nawożenie Density of crop sowing and fertilization}

Duże zagęszczenie roślin $\mathrm{w}$ łanie przez gęstszy siew i zwiększone nawożenie azotowe mogą stanowić barierę rozwoju niektórych gatunków chwastów, a tym samym ograniczyć ich konkurencyjność. Prace różnych autorów (Staniforth i Weber 1956; Pfaiffer i Holmes 1961; Godel 1985) sugerują, że wyższe niż zalecane ilości wysiewu sa jedną z metod walki z chwastami rocznymi w zbożach. Burrows i Olson (1955) podają, że pszenica jara wysiana rzadko wymaga chemicznego odchwaszczania, gdy w łanie wystapi $S$. arvensis w liczbie 54 roślin $/ \mathrm{m}^{2}$. Zwiększenie dwu-, trzykrotnie ilości wysiewu uzasadnia stosowanie herbicydów dopiero przy wystąpieniu tego gatunku w liczbie ponad 238 roślin $/ \mathrm{m}^{2}$. Wyniki badań nad wpływem nawożenia na konkurencyjne oddziaływania chwastów na roślinę uprawną upoważniają do stwierdzenia, że zwiększone nawożenie jest mało efektywne, jeżeli stymuluje rozwój chwastów, zwłaszcza azotolubnych (Thurston 1962; Nalewaja 1964; Rola i Banach 1998). Niestety,

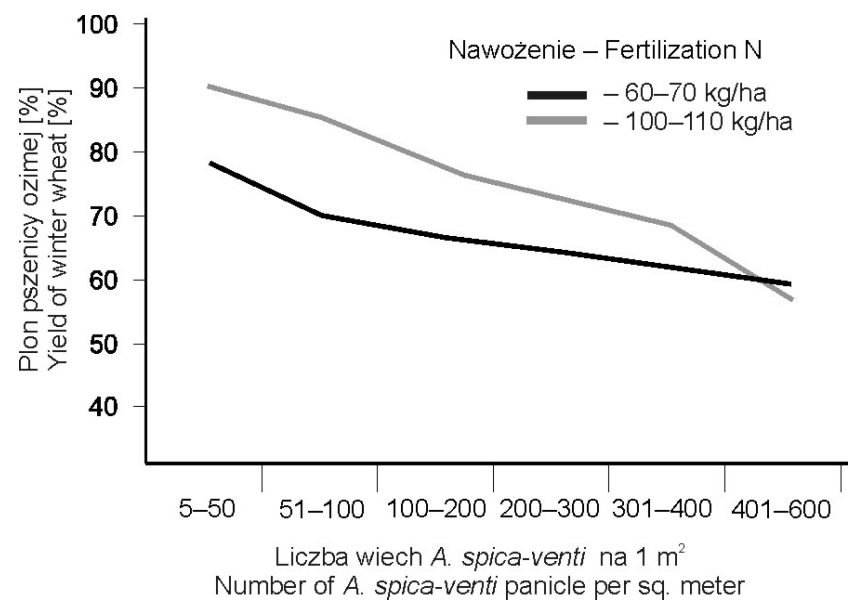

Rys. 3. Wpływ gatunku $A$. spica-venti na plonowanie pszenicy ozimej w zależności od poziomu nawożenia azotem (Rola i Rola 2002)

Fig. 3. Influence of $A$. spica-venti species on the winter wheat yield depend on the level of nitrogen fertilization (Rola i Rola 2002)

w tych badaniach zbyt mało uwagi poświęcono zagadnieniom współdziałania pomiędzy normą wysiewu rośliny uprawnej i poziomem nawożenia a jej plonowaniem w odniesieniu do stanu i stopnia zachwaszczenia. Odmien- ne w tym zakresie wyniki uzyskali Rola (1982), Rola i Gołębiowska (1991) oraz Rola i Banach (1998). Dowodzą one, że nawożenie azotowe stanowi czynnik zmniejszający skutki konkurencyjnego oddziaływania chwastów na pszenicę. W warunkach niskiego zachwaszczenia łanu zwiększenie nawożenia azotowego, zmniejsza straty w plonach zbóż, a tym samym podnosi wielkości progowe zachwaszczenia. $Z$ kolei, podniesienie ilości wysiewu pszenicy na polach, gdzie A. spica-venti występuje w niewielkim nasileniu wpływa korzystnie na plonowanie zboża, przez zwiększenie liczby pędów produkcyjnych, co jest ważnym elementem w procesie konkurencji rośliny uprawnej z chwastami o przestrzeń życiową i podstawowe składniki pokarmowe w glebie (rys. 3).

\section{Poziom plonowania rośliny uprawnej Level of crop yielding}

Do czynników ekologicznych mających związek z progami szkodliwości, należy zaliczyć także poziom plonowania rośliny uprawnej. Wyższe straty w plonach zbóż, pod wpływem zachwaszczenia zachodzą w warunkach wyższego ich plonowania, co znajduje swój wyraz w wielkościach ekonomicznego progu szkodliwości. Zależność tą wykazano na przykładzie miotły zbożowej występującej w pszenicy ozimej (tab. 3).

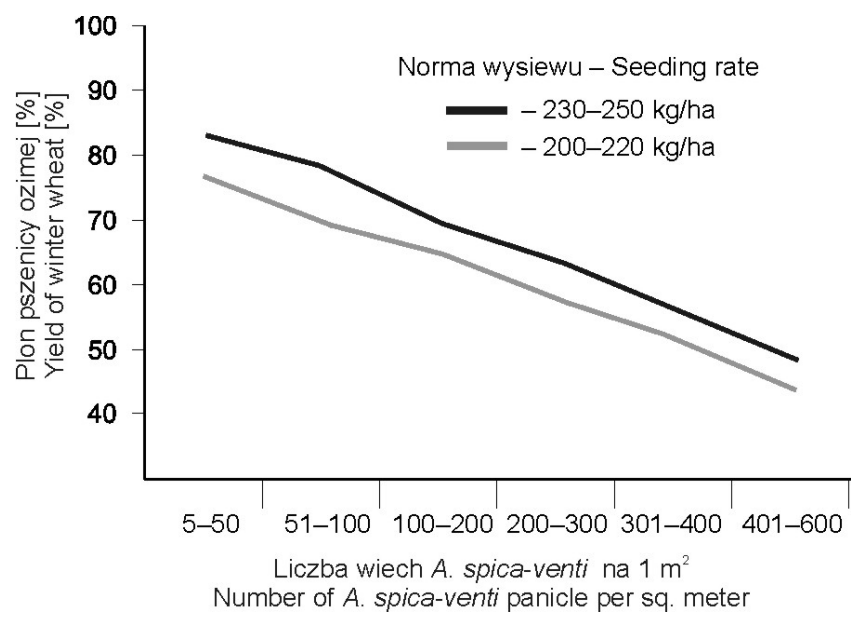

Rys. 4. Wpływ gatunku A. spica-venti na plonowanie pszenicy ozimej w zależności od gęstości wysiewu (Rola i Rola 2002)

Fig. 4. Influence of A. spica-venti species on the winter wheat yield depend on sowing rate (Rola i Rola 2002)

Tabela 3. Wpływ gatunku A. spica-venti na obniżenie plonu pszenicy ozimej [\%] w zależności od poziomu plonowania (Rola 1982) Table 3. Influence of $A$. spica-venti species on winter wheat yield increase [\%] related to yielding level (Rola 1982)

\begin{tabular}{c|c|c|r}
\hline \multirow{2}{*}{$\begin{array}{c}\text { Liczba roślin A.spica-venti na } 1 \mathrm{~m}^{2} \\
\text { Number plants of A. spica-venti per sq. meter }\end{array}$} & $3,5 \mathrm{t} / \mathrm{ha}$ & $4,0-4,5 \mathrm{t} / \mathrm{ha}$ & $5,0-5,5 \mathrm{t} / \mathrm{ha}$ \\
\cline { 2 - 4 } & 13 & 13 & 22 \\
\hline $1-10$ & 14 & 22 & 27 \\
\hline $11-30$ & 35 & 27 & 30 \\
\hline $31-60$ & 70 & 59 & 44 \\
\hline $61-100$ & 70 & 61 & 54 \\
\hline
\end{tabular}




\section{Układ przestrzenny roślin i chwastów w lanie Layout of crop and weeds in field}

Próg szkodliwości tego samego gatunku chwastu może także ulegać wahaniom w zależności od wysokości łanu zboża w jakim występuje. Dowiedziono to na przykładzie A. spica-venti występującej w różnych odmianach pszenicy ozimej. Badania wykazały, że mniejsze straty plonów pszenicy zostały spowodowane obecnością tego gatunku w odmianach średniowysokich, a większe w odmianach o krótkich pędach. Fakt ten jest podstawą wyznaczenia niższego progu szkodliwości $A$. spica-venti dla pszenic ozimych krótkosłomych (Rola 1982). To samo dotyczy odmian celowo skracanych za pomocą bioregulatorów (rys. 5).

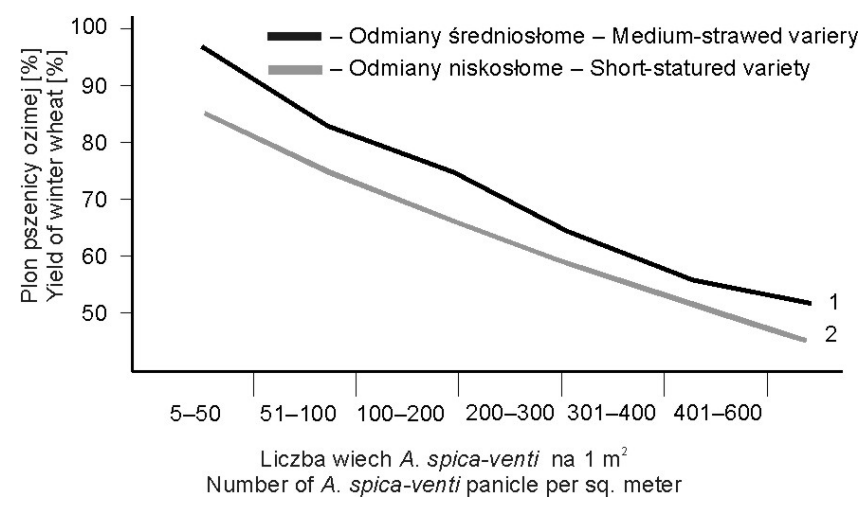

Rys. 5. Wpływ gatunku A. spica-venti na plonowanie pszenicy ozimej w zależności od wysokości źdźbeł (Rola i Rola 2002)

Fig. 5. Influence of $A$. spica-venti species on the winter wheat yield depend on the height of the steam (Rola i Rola 2002)

\section{Zdolność konkurencyjna rośliny uprawnej Competitive ability of crop}

Oddziaływanie rośliny uprawnej na chwasty jest również czynnikiem wpływającym na wielkość progów szkodliwości. Intensywność tego zjawiska zależy w dużej mierze od rozwoju przez roślinę uprawną części nadziemnych oraz podziemnych, a decyduja w tym względzie jej anatomiczne i morfologiczne cechy, takie jak: typ systemu korzeniowego, tempo wzrostu i pobierania wody oraz składników pokarmowych. Wśród roślin uprawnych najmniej podatne na zachwaszczenie jest żyto. Dzięki szybkiemu wzrostowi zagłusza jesienią oraz wczesną wiosną liczne gatunki chwastów ozimych i jarych, a następnie poprzez zacienianie hamuje rozwój nawet E. repens (Koch 1970; Tischler 1971). Na przykład dominacja żyta nad gatunkami $A$. arvensis i $M$. maritima ssp. inodora wynika $\mathrm{z}$ większego przyswajania przez zboże związków azotolubnych (Mann i Barnes 1952). Również brak niektórych mikroelementów w glebie może ograniczać rozwój chwastów i w sposób pośredni decydować o lepszym rozwoju rośliny uprawnej. Tischler (1971) podaje, że $P$. rhoeas, jest bardziej wrażliwy na brak boru, niż wymagające pod tym względem buraki. Omówione wyżej czynniki modyfikujące wielkości progowe zachwaszczenia, upoważniają do uwzględnienia ich w programach decyzyjnych ochrony roślin uprawnych przed chwastami. Zmienność ta w dużym stopniu uzależniona jest także od przebiegu pogody, która hamuje lub stymuluje rozwój zarówno chwastów, jak i rośliny uprawnej.

W praktyce rolniczej znajomość progów ekonomicznej szkodliwości chwastów posiada istotne znaczenie i wzrasta wraz z potrzebą stosowania integrowanej ochrony roślin. Zagadnienie to silnie akcentowali Heitefuss i Wahmhoff (1985), Mierzejewska (1985), Samersov (1994), Sondel (1961), Walker (1977).

W Polsce, pierwsze prace $\mathrm{z}$ tej dziedziny traktowały ogólnie o problemie szkodliwości agrofagów (Stachyra 1968; Demby i Ginter 1976). Podstawową zasadą było poznanie zależności pomiędzy występowaniem określonych gatunków chwastów w łanie, ich nasileniem a plonowaniem rośliny uprawnej. W latach 80. XX wieku trwały już intensywne badania nad wpływem dominujących w łanie taksonów na plonowanie zbóż (Kapeluszny i Pawłowski 1978; Rola 1982, 1983, 1985a, b, 1986), rzepaku ozimego (Rola i Zawadzka 1988; Kapeluszny 1997), kukurydzy (Rola 1986; Rola i Rola 1992a, 1993), buraka cukrowego (Rola i Rola 1990, 1992b). Stwierdzono, że niektóre gatunki chwastów występując w zbożach w niskim nasileniu, powodują obniżenie ich plonowania od 1 do 5\% (Rola 1982). Zatem zastosowanie herbicydu do niszczenia tych gatunków jest ekonomicznie uzasadnione wtedy, gdy wystapią one w łanie w liczbie ponad 10 roślin na $1 \mathrm{~m}^{2}$. Ustalone doświadczalnie progi szkodliwości, dla wybranych gatunków chwastów występujących w pszenicy ozimej przedstawiają się następująco: A. spica-venti 5-10, Anthemideae 2-5, G. aparine $2-5, C$. cyanus $1-5, C$. arvense 1-2 roślin na powierzchni $1 \mathrm{~m}^{2}$ łanu (Rola 1982). Podobne rezultaty zależności plonowania pszenicy ozimej od występowania w niej $A$. spica-venti, C. cyanus, $M$. maritima ssp. inodora stwierdzili Kapeluszny i Pawłowski (1978), Kapeluszny (1986a, b). Kapeluszny (1988a, b) badając inne gatunki, jak: E. repens, A. fatua, $P$. rhoeas, dowodzi także ich konkurencyjnego wpływu na plonowanie zbóż. Przedmiotem szczególnego zainteresowania w ostatnich latach stał się A. myosuroides (Domaradzki i Rola 2006; Kaczmarek i Adamczewski 2007; Domaradzki i wsp. 2010) i B. sterillis (Kaczmarek i Adamczewski 2007).

Zagadnieniem progów szkodliwości chwastów zajmuje się także wiele ośrodków naukowych w innych krajach i rezultaty ich prac są jednoznaczne, co do zamienności wartości progowych zależnie od takich czynników, jak: gatunek chwastu dominujący $\mathrm{w}$ zbiorowisku, roślina uprawna, odmiana, termin siewu, norma wysiewu, obsada na jednostce powierzchni, zawartość składników pokarmowych w glebie, wysokość nawożenia, przebieg pogody, itp.

Z uwagi na fakt, że progi szkodliwości chwastów są wielkościami zmiennymi, zależnymi od warunków siedliska (gleba, poziom agrotechniki, technologie uprawy i pielęgnacji) oraz przebiegu pogody, znajomość takich uwarunkowań w sytuacji wyboru chemicznej ochrony zobowiązuje rolnika do każdorazowej oceny skutków zintegrowania jej z innymi zabiegami odchwaszczającymi. 
W Dyrektywie Parlamentu Europejskiego $\mathrm{z}$ dnia 21.10.2009 (2009/128/WE), artykuł 14 traktuje o integrowanej ochronie roślin następująco: „Państwa członkowskie podejmują wszelkie konieczne środki w celu zachęcania do stosowania ochrony roślin o niskim zużyciu pestycydów, przyznając zawsze, gdy to możliwe, pierwszeństwo metodom niechemicznym, aby profesjonalni użytkownicy pestycydów przechodzili na stosowanie dostępnych praktyk i produktów do walki z danym organizmem szkodliwym, które stwarzają najmniejsze zagrożenie dla zdrowia ludzi i środowiska”. W załączniku III czytamy: „Organizmy szkodliwe muszą być monitorowane przy zastosowaniu odpowiednich metod i narzędzi, jeśli są one dostępne (pkt. 2) i na podstawie wyników działań monitorujących użytkownik profesjonalny musi zdecydować, czy zastosować metody ochrony roślin i kiedy je stosować. Jeśli jest to wykonalne, przed zabiegiem ochrony roślin należy wziać pod uwagę wartości progów szkodliwości dla danego regionu, konkretnego obszaru, uprawy i konkretnych warunków pogodowych".

\section{Podsumowanie / Summation}

Wyniki badań progów szkodliwości potwierdzają konieczność uwzględniania ich w programach integrowanej ochrony roślin przed chwastami. W Polsce dane te nie są jeszcze powszechnie wykorzystywane, chociaż przewiduja to unormowania prawne Unii Europejskiej, które zaczną obowiązywać od roku 2014.

Obecnie wiedza dotycząca progów szkodliwości bez większych przeszkód może być wykorzystana w średnich i dużych gospodarstwach. Ich właściciele i dzierżawcy interesują się nie tylko estetyką łanu, ale także możliwościami ekonomicznego wzrostu efektów gospodarowania. Często posiadają odpowiednie wyposażenie komputerowe, pozwalające na korzystanie $\mathrm{z}$ odpowiednich programów doradczych.

\section{Literatura / References}

Burrows V.D., Olson P.J. 1955. Reaction of small grains to various densities of wild mustard and the results obtained after their removal with 2,4-D or by hand. I. Experiments with wheat. Can. J. Agric. Sci. 35: 68-75.

Demby W., Ginter Z. 1976. Wykaz podstawowych pojęć stosowanych w ekonomice ochrony roślin. Ochrona Roślin 1: 5-6.

Donald C.M. 1951. Competition among pasture plants I. Interspecific competition among annual pasture plants. Aust. Agr. Res. 2: $335-376$.

Domaradzki K., Rola H. 2006. Szkodliwość i możliwości zwalczania Alopecurus myosuroides w warunkach Śląska Opolskiego. Prog. Plant Prot./Post. Ochr. Roślin 46 (1): 233-242.

Domaradzki K., Kucharski M., Marczewska-Kolasa K. 2010. Występowanie i szkodliwość Alopecurus myosuroides Huds. w pszenicy ozimej w południowo-zachodniej Polsce oraz możliwości jego zwalczania. Prog. Plant Prot./Post. Ochr. Roślin 50 (2): $779-784$.

Duer I. 1975. Badania nad konkurencją między gwiazdnicą pospolitą (Stellaria media Vill.) a lucerną siewną (Medicago sativa L.). IUNG Puławy, R (105), 96 ss.

Godel G.L. 1985. Relation between rate of seeding and yield of cereal crops in competition with weeds. Sci. Agr. 16: $165-168$.

Heitefluss R., Wahmhoff W. 1985. Überlegungen zum Konzept der Wirtschaftlichen Schadenschwellen bei der Unkrautbekämpfung. Gesunde Pflanzen 3: 81-86.

Kaczmarek S., Adamczewski K. 2007. Bromus sterilis - chwast ekspansywny, kiełkowanie i progi szkodliwości. Ann. UMCS, Sect. E, $62(2): 17-22$.

Kapeluszny J. 1986a. Badania nad progami szkodliwości miotły zbożowej i owsa głuchego w pszenicy ozimej. Cz. I. Miotła zbożowa. Rocz. Nauk Rol. Seria A, 106 (2): 117-132.

Kapeluszny J. 1986b. Badania nad progami szkodliwości miotły zbożowej i owsa głuchego w pszenicy ozimej. Cz. II. Owies głuchy. Rocz. Nauk Rol. Seria A, 106 (3): 9-23.

Kapeluszny J. 1988a. Krytyczne zagęszczenie maku polnego (Papaver rhoeas L.) w pszenicy ozimej. Zesz. Probl. Post. Nauk Rol. 349: 41-46.

Kapeluszny J. 1988b. Krytyczne zagęszczenie perzu właściwego (Agropyron repens L. P.B.) w pszenicy ozimej. Zesz. Probl. Post. Nauk Rol. 349: 35-40.

Kapeluszny J. 1997. Harmfulness of some dominant weed species for winter oilseed rape (Brassica napus L.). Proc. 10. EWRS Symposium. Poznań, 22-26.06.1997, p. 81.

Kapeluszny J., Pawłowski F. 1978. Próba określenia progu szkodliwości chabra bławatka i maruny bezwonnej w łanie pszenicy ozimej. Rocz. Nauk Rol. Seria A, 103 (3): 25-33.

Koch W. 1970. Unkrautbekämpfung. Ulmer, Stuttgart: 68-76.

Libersztajn I.I. 1981. Zelenyj pożar. Moskwa, Kłos, p. 28.

Mann H.H., Barnes T.W. 1945. The competition between barley and certain weeds under controlled conditions. I. Competition with Spergula arvensis Linn. and Matricaria indora Linn. Ann. Appl. Biol. 15: 15-22.

Mierzejewska W. 1985. Metody badawcze i miary oceny ekonomicznej efektywności chemicznych zabiegów ochrony roślin. Post. Nauk Rol. 5: 77-91.

Nalewaja J.D. 1964. Competition of wild buckwheat in field crops. Proc. North Center. Weed Cont.: 47-55.

Pfaiffer R.K., Holmes H.M. 1961. A study of the competition between barley and oats as influenced by barley seedrate, nitrogen level and barban treatment. Weed Res. 1: 5-18.

Rola H. 1982. Zjawisko konkurencji wśród roślin uprawnych i jej skutki na przykładzie wybranych gatunków chwastów występujących w pszenicy ozimej. Rozprawa habilitacyjna. IUNG, Puławy, R (162), 64 ss.

Rola H. 1985a. Wpływ miotły zbożowej (Apera spica-venti) na plonowanie żyta. Pam. Puł. 83: 121-132. 
Rola H. 1985b. Wpływ owsa głuchego (Avena fatua) na plonowanie pszenicy ozimej i jarej. Pam. Puł. 84: 133-144.

Rola H. 1986a. Zależność wysokości plonów kukurydzy od okresu występowania w łanie Echinochloa crus-galli i Amaranthus retroflexus. Pam. Puł. 87: 155-170.

Rola H. 1986b. Ekonomiczna efektywność chemicznego odchwaszczania pszenicy ozimej. Materiały 26. Sesji Nauk. Inst. Ochr. Roślin, cz. 1: 71-76.

Rola H. 1992. Wpływ stopnia zachwaszczenia ostrożeniem polnym (Cirsium arvense) na plonowanie zbóż. Pam. Puł. 100: 111-120.

Rola J., Banach P. 1998. Współdziałanie herbicydów i nawozów na redukcję zachwaszczenia oraz plon pszenicy ozimej. Prog. Plant Prot./Post. Ochr. Roślin 38 (2): 724-726.

Rola H., Gołębiowska H. 1991. Wpływ zróżnicowanego występowania w łanie gorczycy polnej (Sinapis arvensis) na plonowanie pszenicy jarej w zależności od poziomu nawożenia azotowego i ilości wysiewu. Pam. Puł. 99: 117-127.

Rola H., Rola J. 1983. Competition Apera spica-venti in winter wheat. Proc. 10 Inter. Congress of Plant Protection, Brighton, 1, p. 122.

Rola J., Rola H. 1987. The influence of Galium aparine density, nitrogen fertilization and wheat sowing rate on yield. Proc. 3. Congress on Weeds. Ohrid, 8-10.06.1987. Fragmenta Herbologica Jugoslavica 16 (1-2): 149-153.

Rola H., Rola J. 1990. Wpływ Echinochloa crus-galli na plonowanie buraka cukrowego. Pam. Puł. 96: 147-156.

Rola H., Rola J. 1992a. Competition between Galium aparine and oilseed rape. Proc. 9 Colloque Int. Zur La Biologie des Mauvaises Herbes. Dijon, 2-4.12.1992: 327-335.

Rola H., Rola J. 1992b. Einfluss der Konkurrenz durch Amaranthus retroflexus L. auf den Zukerrüben-und Meisanbau und seine chemischen Bekämpfungsmög-lichkeiten in Südwest-Polen. Proc. 16. Deut. Arbeitsbesprechung über Fragen der Unkrautbiologie und bekampfung. Stuttgart-Hochenheim, 10-12.03.1992. Z. Pflanzenkrankh. Pflanzensch.: 215-220.

Rola H., Rola J. 1993. Konkurenz von Chenopodium album und Echinochloa crus-galli auf mais. Proc. 8. EWRS Symposium. Braunschweig, 14-16.06.1993: 101-106.

Rola H., Rola J. 2002. Progi szkodliwości chwastów w programach decyzyjnych ochrony roślin zbożowych. Prog. Plant Prot./ Post. Ochr. Roślin 42 (1): 332-339.

Rola H., Zawadzka M. 1988. Szkodliwość rumianu polnego (Anthemis arvensis) dla rzepaku ozimego. Materiały 28. Sesji Nauk. Inst. Ochr. Roślin, cz. 2: 247-250.

Samersov V.F. 1994. Zasady opracowania systemów ochrony roślin w integrowanej produkcji roślinnej. Materiały 34 . Sesji Nauk. Instytutu Ochrony Roślin, cz. 1: 79-81.

Staniforth O.W., Weber C.R. 1956. Effects of annual weeds on the growth ans yield of soybeans. Agron. J. 48: 467-471.

Stachyra T. 1968. Próg szkodliwości a próg ekonomiczności zabiegów w ochronie roślin. Ochrona Roślin 2: 16-17.

Sondel J. 1961. Zagadnienia ekonomicznej efektywności ochrony roślin. Zagad. Ekon. Rol. 5: 8-15.

Tischler W. 1971. Agroekologia. PWRiL, Warszawa: 170-172.

Thurston J.M. 1962. The effect of competition from cereal crops on the germination and growth of Avena fatua L. in a naturally infested field. Weed Res. 2: 192-207.

Walker P.T. 1977. Crop losses: Some relationships between field and infestation. Mod. Fac. Landbounw. Rijksuniv. Gent 42 (2): 919-926.

Zimdahl L.R. 1980. Weed-Crop Competition. A Review. Inter. P. Prot. Center. Oregon State University Corvallis Inter. P. Prot. Center, $195 \mathrm{pp}$. 